\title{
Economic impacts of transport and energy infrastructure connecting Asia and Europe: an introductory article for the special issue
}

\author{
Dina Azhgaliyeva ${ }^{1}[$
}

Received: 31 May 2021 / Revised: 31 May 2021 / Accepted: 26 June 2021 /

Published online: 28 July 2021

(๑) The Author(s), under exclusive licence to Springer-Verlag GmbH Germany, part of Springer Nature 2021

The development of trade routes between Asia and Europe will require substantial investments in energy and transport infrastructure in Central Asia, South Asia, and Southeast Asia. Infrastructure investment is a key factor not only for trade but also for economic development and job creation (Yoshino et al. 2021). Attracting greater private sector investment is increasingly critical to bridging the region's nearly $300 \%$ annual infrastructure financing shortfall and building on recent connectivity inroads (Asian Development Bank 2017).

Improving understanding of the economic impacts of infrastructure connecting Asia and Europe is needed to identify and promote policy changes for attracting private finance to sustainably develop infrastructure and promote cross-border trade.

This special issue collects six papers that aim to address some of the above issues. Papers included in this special issue were presented at the Asian Development Bank Institute (ADBI) virtual workshop on "Energy and Transport Infrastructure Connecting Asia and Europe: Investment, Transportation, Trade \& COVID-19" that was held on May 27-29, 2020. Papers for this workshop were selected by the organizing committee from submissions to the ADBI open call for papers which was advertised on ADBI website. During the workshop, all papers received comments from the assigned discussants, other speakers, and audience. In addition, all papers in this special issue went through the journal's double-blind peer-review process.

This special issue features papers that examine the economic and strategic impacts of energy and transport infrastructure connecting Asia and Europe, as well as policies for attracting private finance to sustainably develop new regional projects. Papers in this special issue provide policy recommendations for improving trade and benefiting from infrastructure spillover effects. Main findings demonstrate that infrastructure investments lead to lower trade costs, which lead to greater trade, and

Dina Azhgaliyeva

dazhgaliyeva@adbi.org

1 Asian Development Bank Institute, Kasumigaseki Building 8F, 3-2-5, Kasumigaseki,

Chiyoda-ku, Tokyo 100-6008, Japan 
thus greater employment and economic growth. The magnitude of the infrastructure impact varies across types of transport infrastructure (air, sea, rail, or road), the level of the current development of infrastructure, and the time period passed from investments in infrastructure (short-, medium- or long-term impacts). Infrastructure investments reducing trade costs include not only investments in new transport infrastructure and quality improvements of the existing transport infrastructure but also investments in new cross-border customs and quality improvements of the existing cross-border customs. This raises the importance of transport corridors (Azhgaliyeva and Kalyuzhnova forthcoming).

The paper "Economic Impact of Transportation Infrastructure Investment under the Belt Road Initiative" (Chen and Li 2021) provides an assessment of investments in transportation infrastructure using a computable general equilibrium (CGE) model and data from 42 Eurasian countries over the period 2006-2018. Their results suggest that transportation infrastructure investment tends to significantly reduce interregional trade costs, which will result in significant growth of GDP, employment, and economic welfare. For instance, the total economic impact of investments in transportation infrastructure is greater in South and Southeast Asia than in other regions. In South and Southeast Asia investments in transportation infrastructure increase real GDP by $0.173 \%$ in the short-run and $0.04 \%$ in the long-run on average, While in Central and West Asia investments in transportation infrastructure increase real GDP by $0.0009 \%$ in the short-run and by $0.00032 \%$ in the long-run (Fig. 1). The differences in the impact of investments in transportation infrastructure in two regions are explained by lower investment growth rates in Central and West Asia (0.06\%) comparing to South and Southeast Asia (4.70\%) assumed by the authors in their simulation exercise.

The paper "Does infrastructure facilitate trade connectivity? Evidence from the ASEAN" (Vidya and Taghizadeh-Hesary 2021) explores the impact of infrastructure on trade connectivity among ASEAN and three non-ASEAN countries, India, People's Republic of China, and Japan, using empirical methods and bilateral trade data over the period 1990-2018. Their results show a positive relationship between connectivity and infrastructure and a negative relationship between trade cost and trade connectivity. Thus, policy measures reducing trade costs could improve trade connectivity.

The paper "Competition and Cooperation in the Natural Gas Market: A GameTheoretic Demand-Base Approach" (Chang et al. 2021) analyzes how Russia and Qatar behave in hypothetical scenarios where they diversify their sources of demand, if the competitive landscape today persists, or otherwise in collusive outcomes. Chang et al. (2021) examine the hypothetical scenarios between Russia, the largest exporter of pipeline gas, and Qatar, the largest exporter of LNG using a game-theoretical approach. Their results that in maximizing profits scenario, Russia and Qatar will serve as monopolies in their regional markets and address their respective segmental demand.

The paper "Estimating Causal Effects of BRI Infrastructure Projects Based on the Synthetic Control Method" (Li et al. 2021) studies regional treatment effects of infrastructure projects on employment and transport volumes using the synthetic control in two regions Duisburg and Piraeus. Piraeus represents the maritime 

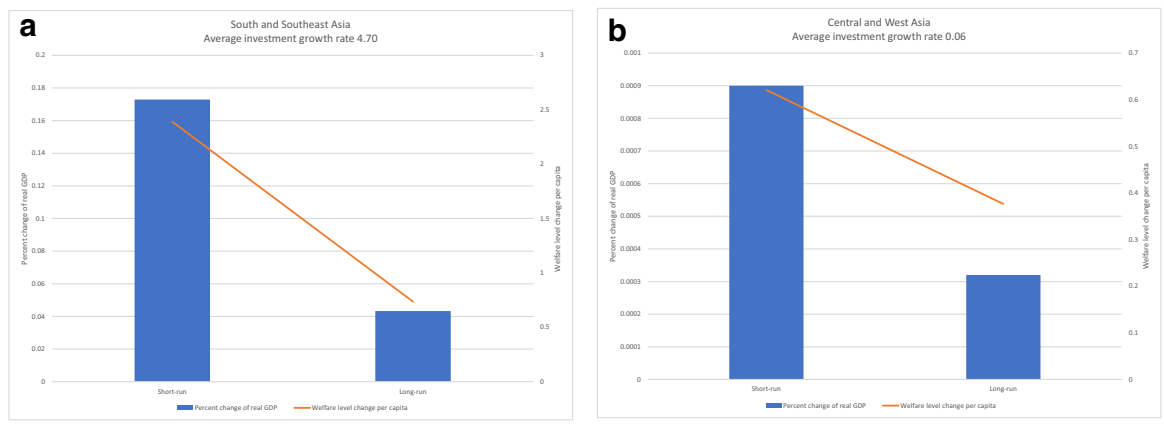

Fig. 1 Simulation results of the economic impact of infrastructure investment. Source: own elaboration using data from Chen and $\mathrm{Li} 2021$

transport mode, whereas Duisburg represents the railway transport mode. Their results show that the impact of infrastructure investments on maritime transportation in Piraeus is very significant. The impact of infrastructure investments is greater in regions with a shortage of infrastructure investments comparing to regions with abundant infrastructure facilities.

The paper "The Impact of Infrastructure on Trade in Central Asia" (Karymshakov and Sulaimanova 2021) investigates the impact of infrastructure on trade in Kazakhstan, the Kyrgyz Republic, and Tajikistan using panel data of the bilateral trade flows from the national statistical agencies of Kazakhstan and the Kyrgyz Republic; as well as from the National Bank of Tajikistan over the period 2010-2018. The average exports and imports of/to Central Asia are USD379 and USD253 million respectively. The major trade partners of Central Asian countries are mainly located in Eurasia. For Kazakhstan, the major trade partners include Italy, the Russian Federation, France, the Netherlands, and the People's Republic of China. For the Kyrgyz Republic, the main trade partners include Kazakhstan, the United Kingdom, the Russian Federation, and Turkey. Major trade partners of Tajikistan are the Russian Federation, the People's Republic of China, Italy, Uzbekistan, Kazakhstan and Turkey. Their results show that both the quality and quantity of infrastructure in Central Asia have a positive impact on trade flows. Based on their empirical evidence, Karymshakov and Sulaimanova (2021) provide the following policy recommendations. Facilitation of regional trade should be based on regional infrastructure development and regional cooperation. The impact of transportation infrastructure varies across types of transportation. For example, $1 \%$ increase in the number of takeoffs of air carriers, would increase exports by $8.9 \%$ and imports by $5.64 \%$. Meanwhile, increasing the total route of rail lines by $1 \%$ leads to an increase of exports by $17.2 \%$ and imports by $17.6 \%$. Infrastructure projects should be supported by other policies that create a favorable environment for international trade facilitation, such as decrease in the regulatory burden.

The paper "China connecting Europe?" (Gruebler 2021) compares the impact from the infrastructure investment projects across the EU countries. The results 
show that the Western Balkans are expected to economically benefit the most among European countries from the BRI, due to high deficiencies in infrastructure.

Acknowledgements The author is thankful to all speakers and audiences of the ADBI virtual workshop on 'Energy and Transport Infrastructure Connecting Asia and Europe: Investment, Transportation, Trade \& COVID-19' that was held on May 27-29, 2020. The author expresses gratitude to the organizing committee members, Peter J. Morgan, Asian Development Bank Institute (ADBI); Alfred Gerstl (Palacký University); and Lixia Yao (National University of Singapore), for their generous support with the call for papers, the workshop, and publication process. The author is also thankful to Ulrich Volz (SOAS University of London) and Alfred Gerstl (Palacký University) for providing a special session on the implications of COVID-19 for infrastructure and trade connectivity during the workshop. I am also thankful to current and former ADBI staff, Ranjeeta Mishra and Kuniko Kondo, for their support in organizing the workshop.

\section{Declarations}

Disclaimer The views expressed in papers included in this special issue are the views of the authors and do not necessarily reflect the views or policies of the Asian Development Bank Institute (ADBI), the Asian Development Bank (ADB), its Board of Directors, or the governments they represent. ADBI does not guarantee the accuracy of the data included in these papers and accepts no responsibility for any consequences of their use. The terminology used may not necessarily be consistent with ADB official terms.

\section{References}

Asian Development Bank (2017) Meeting Asia's infrastructure needs. Mandaluyong City, Philippines: Asian Development Bank. https://www.adb.org/sites/default/files/publication/227496/specialreport-infrastructure.pdf. Accessed 7 July 2021

Azhgaliyeva and Kalyuzhnova (forthcoming) Trans-Caspian Transport Corridor: Infrastructure and Trade, Asian Development Bank Institute. https:/www.adb.org/adbi/publications/books. Accessed 7 July 2021

Chang Y, Trang DTQ, Tan TS, Farhad Taghizadeh-Hesary T (2021) Competition and cooperation in the natural gas market: a game-theoretic demand-base analysis. Asia Eur J. https://doi.org/10.1007/ s10308-021-00615-5

Chen Z, Li X (2021) Economic impact of transportation infrastructure investment under the belt road initiative. Asia Eur J. https://doi.org/10.1007/s10308-021-00617-3

Gruebler J (2021) China connecting Europe? Asia Eur J. https://doi.org/10.1007/s10308-021-00616-4

Karymshakov K, Sulaimanova B (2021) The impact of infrastructure on trade in central Asia. Asia Eur J. https://doi.org/10.1007/s10308-021-00613-7

Li Y, Kleimann M, Schmerer H-J (2021) Estimating causal effects of BRI infrastructure projects based on the synthetic control method. Asia Eur J. https://doi.org/10.1007/s10308-021-00621-7

Naoyuki Y, Bihong H, Azhgaliyeva D, Qaisar A (2021) Developing Infrastructure in Central Asia: Impacts and Financing Mechanisms, Asian Development Bank Institute. https:/www.adb.org/sites/ default/files/publication/688061/adbi-book-developing-infrastructure-central-asia.pdf. Accessed 7 July 2021

Vidya CT, Taghizadeh-Hesary F (2021) Does infrastructure facilitate trade connectivity? Evidence from the ASEAN. Asia Eur J. https://doi.org/10.1007/s10308-021-00614-6

Publisher's note Springer Nature remains neutral with regard to jurisdictional claims in published maps and institutional affiliations. 